\title{
NK Cells and immune activation in HIV-1 infection
}

\author{
Martin R Goodier
}

From $16^{\text {th }}$ International Symposium on HIV and Emerging Infectious Diseases

Marseille, France. 24-26 March 2010

Natural Killer (NK) cells have the potential to eliminate HIV-1 infected target cells and to influence the rate of HIV-1 disease progression. NK cells are, however, depleted during HIV-1 chronic infection and their functions remain diminished in individuals receiving antiretroviral therapy. Chronic immune activation may contribute to loss of NK cell functional potency in HIV-1 infection.

\section{Aims}

Here we investigate the contribution of HIV-1 viraemia and exposure to human cytomegalovirus (HCMV) to chronic NK cell activation and differentiation. We also assess the impact of HIV-1 on NK cells in the gastrointestinal (GI) tract and the association between microbial products translocated from the (GI) tract and chronic activation of NK cells.

\section{Methods}

Blood and colonic lamina propria NK cell activation and differentiation were studied in aviraemic and viraemic HIV-1 infected and HIV-1 seronegative control individuals without or with inflammatory bowel diseases (IBD). NK cell activation and receptor expression were assessed by flow cytometry, CMV exposure by antiHCMV IgG Elisa and plasma lipopolysaccharide (LPS) by limulus amoebocyte assay.

\section{Results}

HIV-1 plasma viraemia has a dominant impact on NK cell losses and chronic NK cell activation whereas differentiation of blood NK cell receptor expression is associated with exposure to HCMV in HIV-1+ individuals. HIV-1 plasma viraemia is also associated with depletion of NK cells in the colonic lamina propria whilst atypical

$$
\text { Department of Immunology, Imperial College London, Chelsea and }
$$$$
\text { Westminster Hospital, London, UK }
$$

gut NK cell differentiation occurs in both HIV-1+ individuals and in HIV-1- IBD patients. Plasma LPS is elevated both in viraemic and aviraemic HIV-1+ individuals and in IBD patients. Chronic NK cell activation is, however, reduced in aviraemic HIV-1+ individuals and is absent in IBD patients.

\section{Discussion}

Depletion and chronic activation of NK cells is associated with HIV-1 viraemia whilst concomitant infections and ongoing inflammatory processes influence functional differentiation of NK cells in the blood and GI tract. These data have implications for innate immune competence in HIV-1 infected individuals.

Published: 11 May 2010

doi:10.1186/1742-4690-7-S1-114

Cite this article as: Goodier: NK Cells and immune activation in HIV-1 infection. Retrovirology 2010 7(Suppl 1):114.

Submit your next manuscript to BioMed Central and take full advantage of:

- Convenient online submission

- Thorough peer review

- No space constraints or color figure charges

- Immediate publication on acceptance

- Inclusion in PubMed, CAS, Scopus and Google Scholar

- Research which is freely available for redistribution

Submit your manuscript at www.biomedcentral.com/submit 